\title{
"Employee critical psychological states as determinants of employee brand equity in banking: a multi-group analysis"
}

\begin{tabular}{|c|c|}
\hline AUTHORS & $\begin{array}{l}\text { Mohsin Altaf } \\
\text { Sany Sanuri Mohd Mokhtar } \\
\text { Noor Hasmini Abd Ghani }\end{array}$ \\
\hline ARTICLE INFO & $\begin{array}{l}\text { Mohsin Altaf, Sany Sanuri Mohd Mokhtar and Noor Hasmini Abd Ghani (2017). } \\
\text { Employee critical psychological states as determinants of employee brand equity } \\
\text { in banking: a multi-group analysis . Banks and Bank Systems, 12(3), 61-73. } \\
\text { doi:10.21511/bbs.12(3).2017.05 }\end{array}$ \\
\hline DOI & http://dx.doi.org/10.21511/bbs.12(3).2017.05 \\
\hline RELEASED ON & Monday, 04 September 2017 \\
\hline RECEIVED ON & Friday, 09 June 2017 \\
\hline ACCEPTED ON & Monday, 31 July 2017 \\
\hline LICENSE & $\begin{array}{l}(c) \text { EY-No } \\
\text { This work is licensed under a Creative Commons Attribution-NonCommercial } 4.0 \\
\text { International License }\end{array}$ \\
\hline JOURNAL & "Banks and Bank Systems" \\
\hline ISSN PRINT & $1816-7403$ \\
\hline ISSN ONLINE & $1991-7074$ \\
\hline PUBLISHER & LLC "Consulting Publishing Company "Business Perspectives" \\
\hline FOUNDER & LLC "Consulting Publishing Company "Business Perspectives" \\
\hline
\end{tabular}

NUMBER OF REFERENCES

42

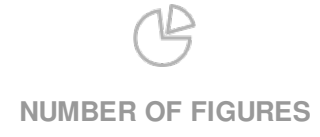

4
NUMBER OF TABLES

4

(C) The author(s) 2023. This publication is an open access article. 


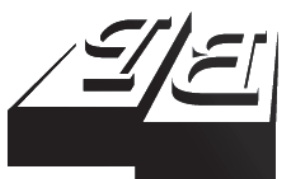

BUSINESS PERSPECTIVES

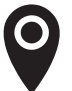

LLC "CPC "Business Perspectives" Hryhorii Skovoroda lane, 10, Sumy, 40022, Ukraine

www.businessperspectives.org

Received on: $9^{\text {th }}$ of June, 2017 Accepted on: $31^{\text {th }}$ of July, 2017

(C) Mohsin Altaf, Sany Sanuri Mohd Mokhtar, Noor Hasmini Abd Ghani, 2017

Mohsin Altaf, School of Business Management, Universiti Utara Malaysia, Malaysia.

Sany Sanuri Mohd Mokhtar, Dr., Professor, School of Business Management, Universiti Utara Malaysia, Malaysia.

Noor Hasmini Abd Ghani, Dr., Associate Professor, School of Business Management, Universiti Utara Malaysia, Malaysia.

\section{(ㄷ)(1) $(9$}

This is an Open Access article, distributed under the terms of the Creative Commons Attribution-NonCommercial 4.0 International license, which permits re-use, distribution, and reproduction, provided the materials aren't used for commercial purposes and the original work is properly cited.
Mohsin Altaf (Malaysia), Sany Sanuri Mohd Mokhtar (Malaysia),

Noor Hasmini Abd Ghani (Malaysia)

\section{EMPLOYEE CRITICAL} PSYCHOLOGICAL STATES AS DETERMINANTS OF EMPLOYEE BRAND EQUITY IN BANKING: A MULTI-GROUP ANALYSIS

\begin{abstract}
$\mathrm{T}^{\text {he }}$ objective of the study is to investigate the moderating role of affective sentiments of brand psychological ownership of an employee on the relationship among the cognitive sentiments of employee brand understanding and employee brand equity of conven- tional and Islamic banks. Survey method was adopted to collect data from respondents from conventional and Islamic banks. Data were collected from 279 employees from the banking sector using two-stage probability sampling. Disproportionate stratified random sampling and simple random sampling were employed to collect respons-es. To analyze the data, multi-group analysis was applied using PLS-SEM technique through SmartPLS 3.0. Results demonstrated that congruence between brand image and individuals has a moderating effect on the relationship between brand confidence and employee brand equity in conventional banking. Responsibility to maintain brand image has a moderating effect on the relationship between brand knowledge and em-ployee brand equity in conventional banking. In case of Islamic banking, only congru-ence between brand image and individuals exhibited a moderating role on the relation-ship between brand knowledge and employee brand equity. The importance of brand understanding of employees and psychological ownership of a brand has been widely discussed in branding literature. However, only a few studies investigated the relation-ship between dimensions of employee brand understanding and the employee brand psychological ownership with employee brand equity. The cognitive and affective sen- timents of both exogenous latent constructs, their relationships, and the interaction ef-fect of cognitive and affective sentiments were seldom discussed in branding literature. $\mathrm{T}^{\mathrm{h}}$ is study covers the in-depth view and investigation of brand understanding of em-ployees and the affective and cognitive sentiments of brand psychological ownership with employee behavior toward a brand. This study also uncovers the moderating role of affective sentiments of brand psychological ownership on the relationship between cognitive sentiments of employee brand understanding and employee brand equity. $\mathrm{T}^{\mathrm{h}}$ is study will help researchers analyze the in-depth role of affective and cognitive sentiments on brand supportive related behavior of employees.
\end{abstract}

Keywords

\section{JEL Classification} ownership, employee brand equity, multi-group analysis

\section{INTRODUCTION}

Islamic banking is separate from conventional banking based on Islamic laws, where the most prestigious books of Islam prohibited interest from life (Ariff, 1988; Zafar, Altaf, Bagram, \& Hussain, 2012). Hence, Islamic banking is interest-free banking. The reflections of Islamic values are not limited to products with "Halal" logo. Islamic values are also seen in services, especially in the banking sector, because of clear Islamic guidelines. At present, Islamic banks hold a major portion of assets and market share around the world (Khan, 2010), because these banks offer a number of 
products and services similar to those offered by conventional banks and these products are consistent with Islamic laws. Islamic and conventional banks offer product and brand values to consumers in different ways. Hence, the people element in services, especially in the banking sector, gives life to the brand and an experience that truly represent brand values (Altaf, Iqbal, Mokhtar, \& Sial, 2017). Brand experiences enable consumers to differentiate the true values of a brand.

Given these factors, the promise of a brand communicated to external stakeholders depends on a bank's ability to deliver its values to establish brand-customer relationship. Bank employees are responsible for the delivery of brand promise. Therefore, bank employees should exhibit work-related attitude and behavior aligned with the brand promise communicated. Thus, managing employee behavior related to the brand is imperative to the success of the brand (Piehler et al., 2016). Moreover, employees are considered important for sustaining competitive advantage when the products and services in the banking sector are relatively homogenous (Mosley, 2007). However, to make brand differentiation through employee behavior, employee brand equity (King \& Grace, 2009, 2010; King, Grace, \& Funk, 2012) is comprehensive models that represent employee behavior. Model covers brand consistent behavior, brand endorsement, and brand allegiance; these models describe employee brand equity as "the differential effect that brand knowledge has on an employee's response to their work environment" (King \& Grace, 2009, p. 130).

In fact, number of studies revolved around the affective perspective of work-related attitude (e.g., Ahn, Hyun, \& Kim, 2015; Kwon, 2013; Piehler, Hanisch, \& Burmann, 2015; Terglav, Ruzzier, \& Kase, 2014). By contrast, the cognitive aspect of work-related attitudes of employees obtained low attention, i.e., brand understanding of employees (Piehler et al., 2016; Xiong, King, \& Piehler, 2013). Both aspects are equally important, because they complete each other (Thomson, de Chernatony, Arganbright, \& Khan, 1999). Without brand understanding, employees cannot identify the meaningfulness of the brand in delivering brand promise (Xiong et al., 2013). The present study investigates the cognitive and affective sentiments of brand understanding of employees with employee brand equity in Islamic and conventional banking.

Brand psychological ownership is another important variable that provides employees the feeling of ownership toward a brand. Brand psychological ownership and employee brand understanding are a mix of different proportion of affective and cognitive sentiments. The combination of cognition and emotion turns employees into brand champions (Thomson et al., 1999). Cognitive sentiments have a weaker relationship with employee brand equity than affective sentiments (King, 2010; King \& Grace, 2010; King et al., 2012) and somehow inconsistent relationships (e.g., Baumgarth \& Schmidt, 2010; Kimpakorn \& Dinnie, 2009). Hence, inconsistencies and weak relationships urge researchers to investigate the moderating role of the affective sentiments of brand psychological ownership (congruence between brand image and individuals and responsibility for maintaining brand image) on the relationship between cognitive sentiments of employee brand understanding (brand knowledge and brand confidence) and employee brand equity. The second objective of this study is to investigate the moderating role of affective sentiments of brand psychological ownership on the relationship between cognitive sentiments of employee brand understanding and employee brand equity.

\section{LITERATURE REVIEW}

\subsection{Employee brand equity}

Employee brand equity is the third perspective of brand equity (King \& Grace, 2009); this concept pertains to the positive and productive employee brand-related behavior that comes from employee knowledge (King \& Grace, 2009). King et al. (2012) conceptualized employee brand eq- uity through consistent brand behavior, brand allegiance, and brand endorsement. Brand consistent behavior is a non-prescribed employee behavior aligned with brand values (Burmann \& Zeplin, 2005), whereas brand endorsement is the extent to which employees are willing to say positive things about the brand and recommend the brand to others (King et al., 2012). Brand allegiance is the likelihood of an employee to continue such a behavior in future. 


\subsection{Employee brand understanding}

Employee brand understanding is the cognitive representation of the brand in the mind of customers (Piehler et al., 2016). Thus, Xiong et al. (2013) conceptualized the construct of employee brand understanding with three dimensions, namely, employee perceived brand knowledge, perceived brand importance, and role relevance; they employed job characteristics theory, which assumes that employees develop different levels of psychological states that come from varying job designs, thereby resulting in different levels of personal and organizational outcomes (Hackman \& Oldham, 1975). The construct of employee brand understanding covers intellectual (brand knowledge) and emotional aspects or sentiments (role relevance and brand importance), which are crucial to the delivery of brand-related promises (Thomson et al., 1999). Piehler et al. (2016) refined the work of Xiong et al. (2013) and added the dimension of brand confidence in the conceptualization of employee brand understanding.

The first component of employee brand understanding is brand confidence. Brand confidence refers to employee knowledge about brand-strengthened behavior that they need to perform in their daily work routine (Piehler et al., 2016). Brand confidence in the strict sense refers specifically to the implementation of brand-strengthened behavior and the associated knowledge structures of employees. Employees must know and understand that the brand promise can be delivered by specific behaviors (Henkel, Tomczak, Heitmann, \& Herrmann, 2007). This type of brand knowledge differs from general brand knowledge and it should be considered separately, because the brand-strengthened behavior of a service employee will differ from that of a sales representative. These two groups of employees must exhibit behavior tailored to their job profile and sophisticated knowledge. This action-oriented knowledge is effective in terms of manifestation of brand-related behavior (Piehler et al., 2016). Hence, we can assume that this brand-strengthened behavioral knowledge is effective in conventional and Islamic banking. Therefore, we offer the following hypothesis.
H1: Brand confidence would have significant relationship with employee brand equity in (a) conventional banking and (b) Islamic banking.

The second component of employee brand understanding is brand relevance. Piehler et al. (2016) defined brand relevance as the concept of brand importance in Xiong et al. (2013), wherein an employee perceives brand as important to organizational success. This perception develops employee attention toward brand performance as meaningful and worthwhile (Xiong et al., 2013), because the potential of employee success is attached to organizational and brand success. This perception is important for achieving the brand-related behavior of employees. According to job characteristics theory, this perception is an important antecedent of organizational success (Hackman \& Oldham, 1975). Hence, it is also an important antecedent in the conventional and Islamic banking sector. We, then, offer the following hypothesis.

H2: Brand relevance would have significant relationship with employee brand equity in (a) conventional banking and (b) Islamic banking.

The third component of employee brand understanding is behavioral relevance. Behavioral relevance is the acknowledgement of an employee that his or her behavior contributes to the success of the brand by contributing toward external brand experience (Piehler et al., 2016). According to job characteristics theory, when employees are responsible for their performance, they are most likely to develop brand-related attitude and behavior (Hackman \& Oldham, 1975). This employee perception facilitates the development of a perception that they are most valuable and responsible to achieve brand-related goals, i.e., enhancing customer experience (Kahn, 1990). Similar to the banking sector, employees can enhance customer experience if they perceive that they are most valuable in achieving branding goals. We, then, offer the following hypothesis.

H3: Behavioral relevance would have significant relationship with employee brand equity in (a) conventional banking and (b) Islamic banking. 
The fourth dimension of employee brand understanding is the perceived brand knowledge of employees, which that entails employee perception of what the brand stands for and it wants to deliver. Employees use their brand knowledge as an effective signal to perform in their organization, especially when dealing with unexpected problems in service encounters (Xiong et al., 2013). Thus, when employees are clearly aware of their role in providing brand-aligned experience, they tend to have less confusion. In particular, brand understanding is a prerequisite for an employee's capability to deliver the brand promise and is necessary for achieving the brand-related behavior of the employees. Based on discussions, we, then, postulate the following hypothesis.

H4: Behavioral knowledge would have significant relationship with employee brand equity in (a) conventional banking and (b) Islamic banking.

\subsection{Brand psychological ownership}

Psychological ownership is the feeling of ownership toward things that are substantial and non-substantial and are tangible or intangible (Pierce, Kostova, \& Dirks, 2001, 2003). Psychological ownership is different from lawful possession. People have the capability of developing psychological ownership through their psychological experiences without acquiring legal ownership (Rousseau \& Shperling, 2003). Similarly, Chang, Chiang, and Han (2012) defined brand psychological ownership as an employee psychological experience that produces positive and brand-related attitude and cognition, such as feeling of possession toward a brand; they conceptualized brand psychological ownership with three dimensions, namely, congruence between brand image and individual, responsibility of maintaining brand image, and brand value effectiveness. According to social exchange theory, employees who develop psychological ownership toward a brand may reciprocate the brand by acting selflessly and developing brand-related behavior (Chang et al., 2012). We then postulate the following hypotheses.

H5: Congruence between brand image and individuals would have positive relationship with employee brand equity in (a) conventional banking and (b) Islamic banking.
H6: Responsibility for maintaining brand image would have positive relationship with employee brand equity in (a) conventional banking and (b) Islamic banking.

H7: Brand value effectiveness would have positive relationship with employee brand equity in (a) conventional banking and (b) Islamic banking.

In terms of theoretical point of view, affective event theory discusses the belief toward a job from emotional experiences in the workplace (Van Dyne \& Pierce, 2004). This theory proposed that different attitudes have different mix or different proportions of affective and cognitive elements (Weiss \& Cropanzano, 1996). By extending the idea of affective event theory, psychological ownership differs from other work-related attitudes given its unique explanatory power; the conceptual core triggers of this theory affect driven behavior, whereas emotional core transcends the cognitive evaluation of the firm (Van Dyne \& Pierce, 2004).

Similar to psychological ownership, employee brand understanding also comprises emotional and intellectual capital (Thomson et al., 1999; Xiong et al., 2013); however, the internalization of brand information transforms employees toward their job actions. According to Thomson et al. (1999), the combination of intellectual and emotional capital transform employees into brand champions. Hence, consistent with the claim raised by Thomson et al. (1999), we argue that affective sentiments of brand psychological ownership (congruence between brand image and individuals and responsibility for maintaining brand image) can moderate the relationship between cognitive sentiments of employee brand understanding (brand knowledge and brand confidence) and employee brand equity. We, then, offer the following hypotheses.

H8: Congruence between brand image and individuals moderates the relationship between brand confidence and employee brand equity in (a) conventional banking and (b) Islamic banking.

H9: Responsibility for maintaining brand image moderates the relationship between brand confidence and employee brand equity in (a) conventional banking and (b) Islamic banking. 
H10: Congruence between brand image and individuals moderates the relationship between brand knowledge and employee brand equity in (a) conventional banking and (b) Islamic banking.

H11: Responsibility for maintaining brand image moderates the relationship between brand knowledge and employee brand equity in (a) conventional banking and (b) Islamic banking.

\section{THEORETICAL} FRAMEWORK

\section{METHODOLOGY}

To analyze the proposed hypotheses of study, theoretical framework was designed in Figure 1. The following section will describe the methodology to conduct the research.

\subsection{Instrumentation}

This study relies on self-administration. The scales were adapted from existing studies. Employee brand equity is the endogenous latent construct in the study. Employee brand equity is the positive and productive employee brand-related behavior that comes from brand knowledge (King \& Grace, 2010). Employee brand equity is a mul-

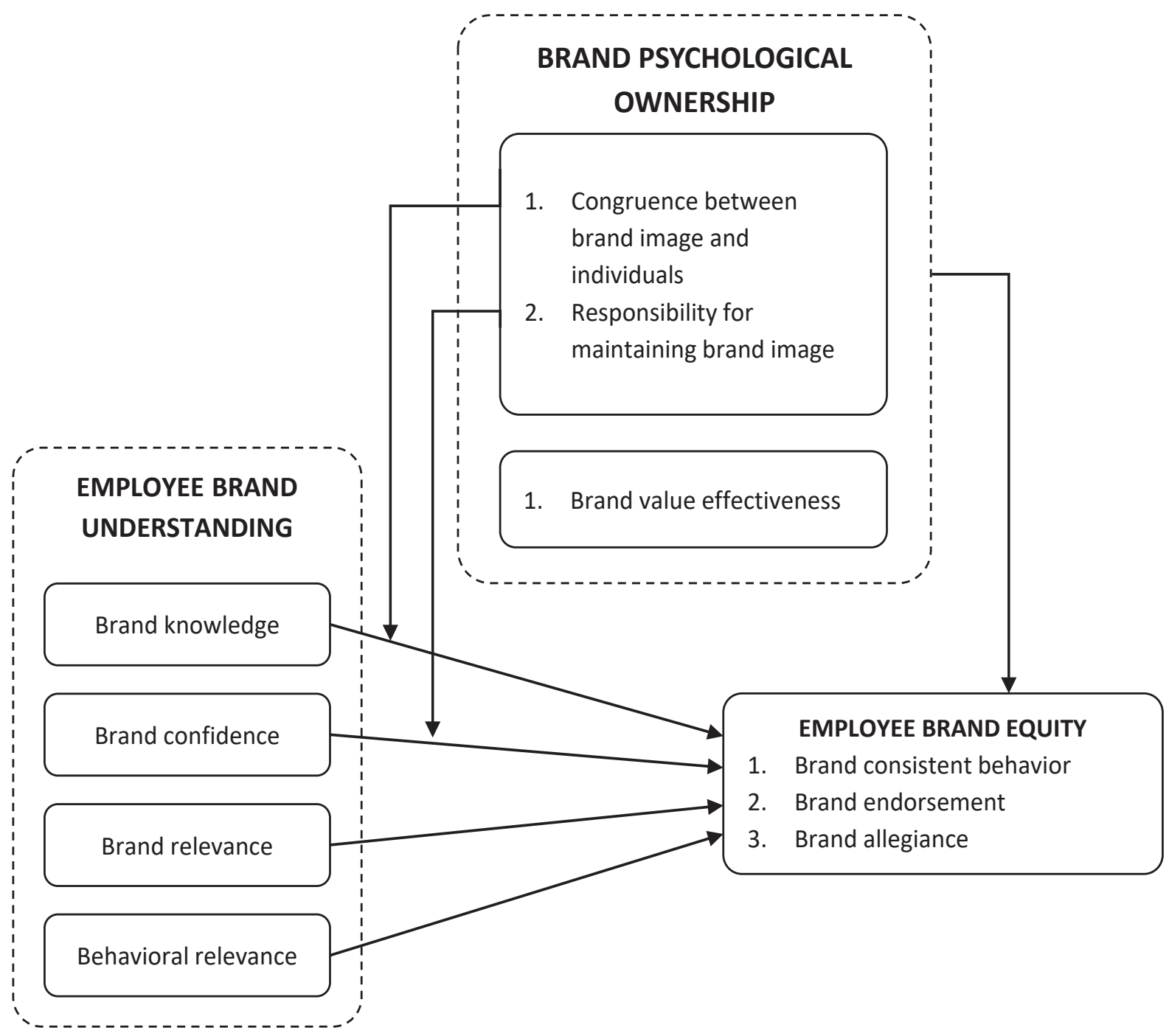

Figure 1. Research framework 
tidimensional construct, which includes brand consistent behavior, brand allegiance, and brand endorsement. The i tems $u$ sed $\mathrm{f}$ or $\mathrm{m}$ easuring $\mathrm{t}$ he three dimensions of employee brand equity was adapted from the study of King and Grace (2010). The i tems u sed to m easure the four d imensions of employee brand understanding were obtained from the study of Piehler et al. (2016). Employee brand understanding is the cognitive representation of a brand in the mind of consumers (Piehler et al., 2016). Employee brand understanding is the exogenous latent variable of the study. For moderating variable, 9 items to measure three dimension of brand psychological ownership were adapted from the study of Chang, Chiang, \& Han (2012). All the dimensions of three adapted scales are reflective in nature and all the items were measured using a six-point Likert-type scale that ranged from $1=$ strongly disagree to $6=$ strongly agree. This study included 33 items to measure the three constructs other than demographic variables.

\subsection{Sampling procedure and data collection}

This study was based on cross-sectional approach. A total of 400 questionnaires were distributed to employees in conventional banks and Islamic banks. Data were collected from the region of Punjab, Pakistan, because $56.45 \%$ of bank branches are located in this region. The survey was conducted from October 2016 to February 2017.

The population of this study is composed of employees working in conventional and Islamic commercial banks. Approximately 152,896 employees work in 28 conventional and Islamic commercial banks in Pakistan; 17,883 employees work in five Islamic banks. According to Krejcie and Morgan (1970), the sample size of 377 is sufficient to represent the population. Multistage sampling method was adopted to select the sample, which include disproportionate stratified random sampling and simple random sampling. To collect data from the employees of bank branches, five questionnaires were distributed to 40 conventional bank branches and 40 Islamic bank branches. A total of 200 questionnaires were distributed to the employees of conventional banks and 200 distributed to the employees of Islamic banks. Bank employees were also selected through simple random sampling using a random number table proposed by Rand Corporation (Corporation, 2001). Only 292 questionnaires were returned. Our yielded response rate was $73 \%$. Thirteen problematic responses were discarded because of incomplete answers. Hence, 279 questionnaires were used for further data analysis. Therefore, the effective response rate was $69.75 \%$. Specifically, $162(81 \%)$ valid responses were received from conventional banks and $117(58.5 \%)$ valid responses received from Islamic banks.

\section{STATISTICAL ANALYSIS}

\subsection{Measurement of the outer model}

Data were analyzed using SmartPLS 3.2 by Ringle, Wende, and Becker (2015). The results of standardized loadings, AVE and CR for each model of the study are described in Table 1 to access the outer model. Recommended threshold level for standardized loading is 0.70 (Hair, Hult, Ringle, \& Sarstedt, 2013), but if the value is low and the AVE is higher than 0.50, therefore, no need to remove the item from group (Hair, Hult, Ringle, \& Sarstedt, 2016). Hence, no item was deleted from the dataset for further analysis. In last, all the values of CR also exceeding the threshold level of 0.70 for both the models as suggested by Nunnally (1978).

Discriminant validity was assessed through the criteria suggested by Fornell and Larcker (1981). The results of discriminant validity of both models are described in Table 2. All the correlation values of conventional banks and Islamic banks are lower than the square root of average variance extracted of each construct vertically and horizontally. All the values in Table 2 confirm the discriminant validity for both of cases.

\subsection{Measurement of structural model}

For structural model, bootstrapping resample's 5000 generates the value of $\mathrm{t}$-statistics and the standard error to check the significance of path coefficients as recommended by Henseler, Ringle, and Sarstedt (2015). 
Table 1. Instrument, standardized loadings, AVE, CR and Cronbach's alpha

\begin{tabular}{|c|c|c|c|c|c|c|c|c|}
\hline \multirow{2}{*}{ First order } & \multirow{2}{*}{ Second order } & \multirow{2}{*}{ Item labeling } & \multicolumn{3}{|c|}{ Conventional banking } & \multicolumn{3}{|c|}{ Islamic banking } \\
\hline & & & Loadings & AVE & CR & Loadings & AVE & $\mathbf{C R}$ \\
\hline \multicolumn{9}{|c|}{ Brand psychological ownership } \\
\hline \multirow{3}{*}{ CON } & & BPO_CON1 & 0.818 & 0.688 & 0.868 & 0.821 & 0.647 & 0.846 \\
\hline & & BPO_CON2 & 0.812 & & & 0.817 & & \\
\hline & & BPO_CON3 & 0.856 & & & 0.775 & & \\
\hline \multirow{3}{*}{ RES } & & BPO_RES4 & 0.805 & 0.649 & 0.846 & 0.872 & 0.688 & 0.869 \\
\hline & & $\mathrm{BPO} \_$RES5 & 0.752 & & & 0.812 & & \\
\hline & & BPO_RES6 & 0.860 & & & 0.804 & & \\
\hline \multirow{3}{*}{ EFF } & & BPO_EFF7 & 0.737 & 0.625 & 0.833 & 0.793 & 0.671 & 0.859 \\
\hline & & $\mathrm{BPO} \_$EFF8 & 0.784 & & & 0.795 & & \\
\hline & & BPO_EFF9 & 0.849 & & & 0.867 & & \\
\hline \multicolumn{9}{|c|}{ Employee brand equity } \\
\hline \multirow{4}{*}{ BE } & & EBE_EN1 & 0.807 & & & 0.832 & & \\
\hline & & EBE_EN2 & 0.75 & & & 0.664 & & \\
\hline & & EBE_EN3 & 0.794 & & & 0.793 & & \\
\hline & & EBE_EN4 & 0.812 & & & 0.671 & & \\
\hline \multirow{4}{*}{ Bal } & & EBE_BA5 & 0.689 & & & 0.785 & & \\
\hline & & EBE_BA6 & 0.691 & & & 0.691 & & \\
\hline & & EBE_BA7 & 0.755 & & & 0.607 & & \\
\hline & & EBE_BA8 & 0.804 & & & 0.866 & & \\
\hline \multirow{6}{*}{ ВCB } & & EBE_BCB9 & 0.795 & & & 0.706 & & \\
\hline & & EBE_BCB10 & 0.713 & & & 0.696 & & \\
\hline & & EBE_BCB11 & 0.839 & & & 0.832 & & \\
\hline & \multirow{3}{*}{ EBE } & Ben & 0.889 & 0.733 & 0.892 & 0.919 & 0.834 & 0.938 \\
\hline & & Bal & 0.860 & & & 0.920 & & \\
\hline & & ВСВ & 0.818 & & & 0.900 & & \\
\hline \multicolumn{9}{|c|}{ Employee brand understanding } \\
\hline \multirow{4}{*}{ BC } & & EBU_BC1 & 0.77 & 0.576 & 0.843 & 0.764 & 0.491 & 0.791 \\
\hline & & $E B \cup \_B C 2$ & 0.803 & & & 0.557 & & \\
\hline & & EBU_BC3 & 0.85 & & & 0.827 & & \\
\hline & & EBU_BC4 & 0.587 & & & 0.623 & & \\
\hline \multirow{3}{*}{ BR } & & EBU_BR5 & 0.85 & 0.671 & 0.860 & 0.522 & 0.495 & 0.739 \\
\hline & & EBU_BR6 & 0.805 & & & 0.856 & & \\
\hline & & EBU_BR7 & 0.803 & & & 0.692 & & \\
\hline \multirow{3}{*}{ BeR } & & EBU_BeR8 & 0.783 & 0.630 & 0.836 & 0.835 & 0.618 & 0.829 \\
\hline & & EBU_BeR9 & 0.791 & & & 0.778 & & \\
\hline & & EBU_BeR10 & 0.807 & & & 0.743 & & \\
\hline \multirow{3}{*}{ BK } & & EBU_BK11 & 0.845 & 0.657 & 0.851 & 0.938 & 0.764 & 0.907 \\
\hline & & $\mathrm{EBU} \_\mathrm{BK} 12$ & 0.783 & & & 0.844 & & \\
\hline & & EBU_BK13 & 0.801 & & & 0.837 & & \\
\hline
\end{tabular}

Note: $\mathrm{BC}=$ brand confidence, $\mathrm{BR}=$ brand relevance, $\mathrm{BeR}=$ behavioral relevance, $\mathrm{BK}=$ brand knowledge, $\mathrm{EBE}=$ employee brand equity, $\mathrm{BCB}=$ brand consistent behavior, $\mathrm{Bal}=$ brand allegiance, $\mathrm{BE}=$ brand endorsement, $\mathrm{EFF}=$ brand value effectiveness, RES = Responsibility of maintaining brand image, $\mathrm{CON}=$ congruence between brand image and individual, $\mathrm{EBE}=$ employee brand equity, AVE = average variance extracted, $\mathrm{CR}=$ composite reliability. 
Table 2. Discriminant validity

\begin{tabular}{|c|c|c|c|c|c|c|c|c|}
\hline Variables & 1 & 2 & 3 & 4 & 5 & 6 & 7 & 8 \\
\hline \multicolumn{9}{|c|}{ Conventional banking } \\
\hline 1. Behavioral relevance & 0.794 & & & & & & & \\
\hline 2. Brand confidence & 0.667 & 0.759 & & & & & & \\
\hline 3. Brand knowledge & 0.759 & 0.642 & 0.810 & & & & & \\
\hline 4. Brand relevance & 0.662 & 0.661 & 0.687 & 0.819 & & & & \\
\hline 5. Congruence & 0.609 & 0.691 & 0.554 & 0.588 & 0.829 & & & \\
\hline 6. Effectiveness & 0.600 & 0.602 & 0.561 & 0.464 & 0.589 & 0.790 & & \\
\hline 7. Employee brand equity & 0.677 & 0.678 & 0.678 & 0.612 & 0.620 & 0.489 & 0.856 & \\
\hline 8. Responsibility & 0.670 & 0.620 & 0.674 & 0.578 & 0.696 & 0.740 & 0.635 & 0.805 \\
\hline \multicolumn{9}{|c|}{ Islamic banking } \\
\hline 1. Behavioral relevance & 0.818 & & & & & & & \\
\hline 2. Brand confidence & 0.738 & 0.754 & & & & & & \\
\hline 3. Brand knowledge & 0.780 & 0.696 & 0.853 & & & & & \\
\hline 4. Brand relevance & 0.747 & 0.662 & 0.673 & 0.790 & & & & \\
\hline 5. Congruence & 0.779 & 0.766 & 0.754 & 0.700 & 0.804 & & & \\
\hline 6. Effectiveness & 0.584 & 0.633 & 0.543 & 0.571 & 0.741 & 0.819 & & \\
\hline 7. Employee brand equity & 0.778 & 0.774 & 0.722 & 0.767 & 0.747 & 0.633 & 0.913 & \\
\hline 8. Responsibility & 0.654 & 0.638 & 0.584 & 0.585 & 0.664 & 0.689 & 0.648 & $0.830 *$ \\
\hline
\end{tabular}

Note: bold figures are the square root of AVE.

As for as the structural relationships are concerned (Table 3), the first hypothesis posit that $\mathrm{BC}$ having positive relationship with EBE. In the case of conventional banks and Islamic banks, $\mathrm{BC}$ significantly influenced EBE having value $(\beta=0.262$, $t$-value $\left.=2.910, \mathrm{f}^{2}=0.064\right)$ and $(\beta=0.269$, $\mathrm{t}$-value $=3.358$, $\left.\mathrm{f}^{2}=0.085\right)$, respectively. The results of the study indicated that the BR have no influence on EBE in case of conventional banking having value $(\beta=0.047$, $\mathrm{t}$-value $=0.564, \mathrm{f}^{2}=0.002$ ), but in the case of Islamic banking, BR significantly influence EBE having value $\left(\beta=0.305\right.$, $\mathrm{t}$-value $\left.=3.902, \mathrm{f}^{2}=0.144\right)$. The results of the study indicated that BeR significantly influence $\mathrm{EBE}$ in conventional banking $(\beta=0.185$, $\mathrm{t}$-value $\left.=1.797, \mathrm{f}^{2}=0.029\right)$ and non-significant relationship in Islamic banking ( $\beta=0.115$, t-val$\left.\mathrm{ue}=1.227, \mathrm{f}^{2}=0.011\right)$. Results of the study indicated that BC significantly influence EBE in conventional banking having value ( $\beta=0.216$, $t$-value $=2.246$, $\left.\mathrm{f}^{2}=0.0 .039\right)$, but significant in case of Islamic banking $\left(\beta=0.128\right.$, $\mathrm{t}$-value $\left.=1.759, \mathrm{f}^{2}=0.021\right)$.

The abovementioned hypotheses were representing employee brand understanding. As for as the relationship of brand psychological ownership and $\mathrm{EBE}$ is concerned, CON significantly influences $\mathrm{EBE}$ having value $(\beta=0.128$, $\mathrm{t}$-value $=1.666$, $\left.\mathrm{f}^{2}=0.017\right)$ in case of conventional banking and nonsignificant in case of Islamic banking $(\beta=0.041$, $\mathrm{t}$-value $\left.=0.339, \mathrm{f}^{2}=0.001\right)$. Moreover, RES significantly influence EBE having value in conventional banking $\left(\beta=0.191\right.$, $\mathrm{t}$-value $\left.=2.050, \mathrm{f}^{2}=0.028\right)$, but non-significant in Islamic banking ( $\beta=0.070$, $\mathrm{t}$-value $=1.840, \mathrm{f}^{2}=0.088$ ). Lastly, Eff significantly influenced EBE in conventional banking system $\left(\beta=0.140, t\right.$-value $\left.=1.685, f^{2}=0.021\right)$, but non-significant in Islamic banking ( $\beta=0.073$, $\mathrm{t}$-value $=0.806$, $\mathrm{f}^{2}=0.008$ ). All the exogenous variables having $61 \%$ of the variance in the case of conventional banking, but $74.6 \%$ in the case of Islamic banking. Moreover, the value of $\mathrm{R} 2$ shows the predictive validity of the model. Additionally, predictive relevance was measured through the Stone-Geisser Q-Square test for predictive relevance (Geisser, 1975; Stone, 1974). All the values of $\mathrm{Q}^{2}$ greater than zero show the predictive relevance of the model.

Results of the regression analysis in Table 4 represent the results of moderation analyses. In model 1, all the cognitive sentiments of exogenous variable 
Table 3. Structural model path analysis

\begin{tabular}{|c|c|c|c|c|c|c|c|c|}
\hline Hypotheses/ Paths & $\boldsymbol{\beta}$ & S.E & t-value & Decision & VIF & $\mathbf{f}^{2}$ & $\mathbf{Q}^{2}$ & $\mathbf{R}^{2}$ \\
\hline \multicolumn{9}{|c|}{ Conventional banking } \\
\hline H1a: $B C \rightarrow E B E$ & 0.262 & 0.090 & 2.910 & Supported & 2.736 & 0.064 & 0.254 & 0.610 \\
\hline H2a: $B R \rightarrow E B E$ & 0.047 & 0.083 & 0.564 & Not supported & 2.400 & 0.002 & & \\
\hline H3a: $\mathrm{BeR} \rightarrow \mathrm{EBE}$ & 0.185 & 0.103 & 1.797 & Supported & 3.019 & 0.029 & & \\
\hline H4a: BK $\rightarrow$ EBE & 0.216 & 0.096 & 2.246 & Supported & 3.044 & 0.039 & & \\
\hline H5a: CON $\rightarrow E B E$ & 0.128 & 0.077 & 1.666 & Supported & 2.539 & 0.017 & & \\
\hline H6a: RES $\rightarrow$ EBE & 0.191 & 0.093 & 2.050 & Supported & 3.363 & 0.028 & & \\
\hline H7a: $\mathrm{EFF} \rightarrow \mathrm{EBE}$ & -0.14 & 0.083 & 1.685 & Supported & 2.451 & 0.021 & & \\
\hline \multicolumn{9}{|c|}{ Islamic banking } \\
\hline $\mathbf{H} \mathbf{1 b}: \mathrm{BC} \rightarrow \mathrm{EBE}$ & 0.269 & 0.080 & 3.364 & Supported & 3.358 & 0.085 & 0.352 & 0.746 \\
\hline $\mathbf{H} \mathbf{2 b}: \mathrm{BR} \rightarrow \mathrm{EBE}$ & 0.305 & 0.078 & 3.902 & Supported & 2.547 & 0.144 & & \\
\hline H3b: BeR $\rightarrow$ EBE & 0.115 & 0.094 & 1.227 & Not supported & 4.583 & 0.011 & & \\
\hline $\mathbf{H} \mathbf{4 b}: \mathrm{BK} \rightarrow \mathrm{EBE}$ & 0.128 & 0.088 & 1.759 & Supported & 3.045 & 0.021 & & \\
\hline $\mathbf{H} \mathbf{5} \mathbf{b}: \mathrm{CON} \rightarrow \mathrm{EBE}$ & 0.041 & 0.121 & 0.339 & Not-Supported & 4.456 & 0.001 & & \\
\hline H6b: RES $\rightarrow$ EBE & 0.070 & 0.083 & 1.840 & Supported & 2.378 & 0.088 & & \\
\hline $\mathbf{H 7 b}: \mathrm{EFF} \rightarrow \mathrm{EBE}$ & 0.073 & 0.091 & 0.806 & Not supported & 2.729 & 0.008 & & \\
\hline
\end{tabular}

Note: $\mathrm{BC}=$ brand confidence, $\mathrm{BR}=$ brand relevance, $\mathrm{BeR}=$ behavioral relevance, $\mathrm{BK}=$ brand knowledge, $\mathrm{EBE}=\mathrm{employee}$ brand equity, $\mathrm{CON}$ = congruence between brand image and individuals, RES = responsibility for maintaining brand image, $\mathrm{EFF}=$ brand value effectiveness.

( $\mathrm{BC}$ and $\mathrm{BK})$ were regressed over endogenous variable (EBE). In model 2, cognitive sentiments of exogenous variable (BC and $\mathrm{BK}$ ) and affective sentiments of moderator (CON and RES) were regressed over EBE. In model 3, cognitive sentiments of exogenous variable (BC and $\mathrm{BK}$ ), affective sentiments of moderator (CON and RES) and interaction of cognitive and affective sentiments $(\mathrm{BC} \times \mathrm{CON}, \mathrm{BC} \times \mathrm{RES}, \mathrm{BK} \times$ $\mathrm{CON}$ and $\mathrm{BK} \times \mathrm{RES}$ ) were regressed over $\mathrm{EBE}$.
In case of conventional banking, $\mathrm{CON}$ significantly moderates the relationship of $\mathrm{BC}$ and EBE having value $(\beta=0.113$, $t$-value $=1.975)$ and RES significantly moderates the relationship between BK and EBE having value $(\beta=0.188$, $\mathrm{t}$-value $=1.710)$. Hence, hypotheses $8 \mathrm{a}, 11 \mathrm{a}$ are accepted and 9a, 10a were rejected. Moreover, in case of Islamic banking, only CON moderates the relationship between BK and EBE hav-

Table 4. Moderation results

\begin{tabular}{|c|c|c|}
\hline Paths & $\begin{array}{c}\text { Conventional banks } \\
\beta \text { (t-value) }\end{array}$ & $\begin{array}{c}\text { Islamic banks } \\
\beta \text { (t-value) }\end{array}$ \\
\hline \multicolumn{3}{|l|}{ Direct effect } \\
\hline $\mathrm{BC}$ & $0.302(3.311)$ & $0.366(3.369)$ \\
\hline BK & $0.298(3.443)$ & $0.231(2.201)$ \\
\hline CON & $0.069(0.713)$ & $0.189(1.556)$ \\
\hline RES & $0.166(1.662)$ & $0.145(1.353)$ \\
\hline \multicolumn{3}{|l|}{ Interaction effect } \\
\hline $\mathrm{BC} \times \mathrm{CON}$ & $0.113(1.975)$ & $0.076(0.575)$ \\
\hline$B C \times R E S$ & $0.088(1.056)$ & $0.001(0.010)$ \\
\hline $\mathrm{BK} \times \mathrm{CON}$ & $0.013(0.151)$ & $0.150(1.749)$ \\
\hline BK $\times$ RES & $0.188(1.710)$ & $0.086(0.713)$ \\
\hline
\end{tabular}

Note: $\mathrm{t}$-value $>1.645$ means the values are significant on one tail at bootstrap $5000 . \mathrm{BC}=$ brand confidence, $\mathrm{BR}=$ brand relevance, $\mathrm{BeR}=$ behavioral relevance, $\mathrm{BK}=$ brand knowledge, $\mathrm{EBE}=$ employee brand equity, $\mathrm{CON}=$ congruence between brand image and individuals, RES = responsibility for maintaining brand image, $\mathrm{EFF}=$ brand value effectiveness. 
ing value $(\beta=0.150$, $t$-value $=1.749)$. Hence, hy- The effect of $B C$ on EBE in the condition when CON pothesis $10 \mathrm{~b}$ was accepted and $8 \mathrm{~b}, 9 \mathrm{~b}, 11 \mathrm{~b}$ were rejected.

Additionally, simple slope test analysis was conducted to provide the further evidence of the significance of moderating effect on the relationships. is low and high as represented in Figure 2. In the case when $\mathrm{CON}$ is low, the impact of $\mathrm{BC}$ on $\mathrm{EBE}$ is not substantial, as compared to the situation when CON is high. Differently, high level of $\mathrm{BC}$ and CON having substantial impact on EBE, as compared to other situations when either $\mathrm{BC}$ or CON are low in conventional banking.

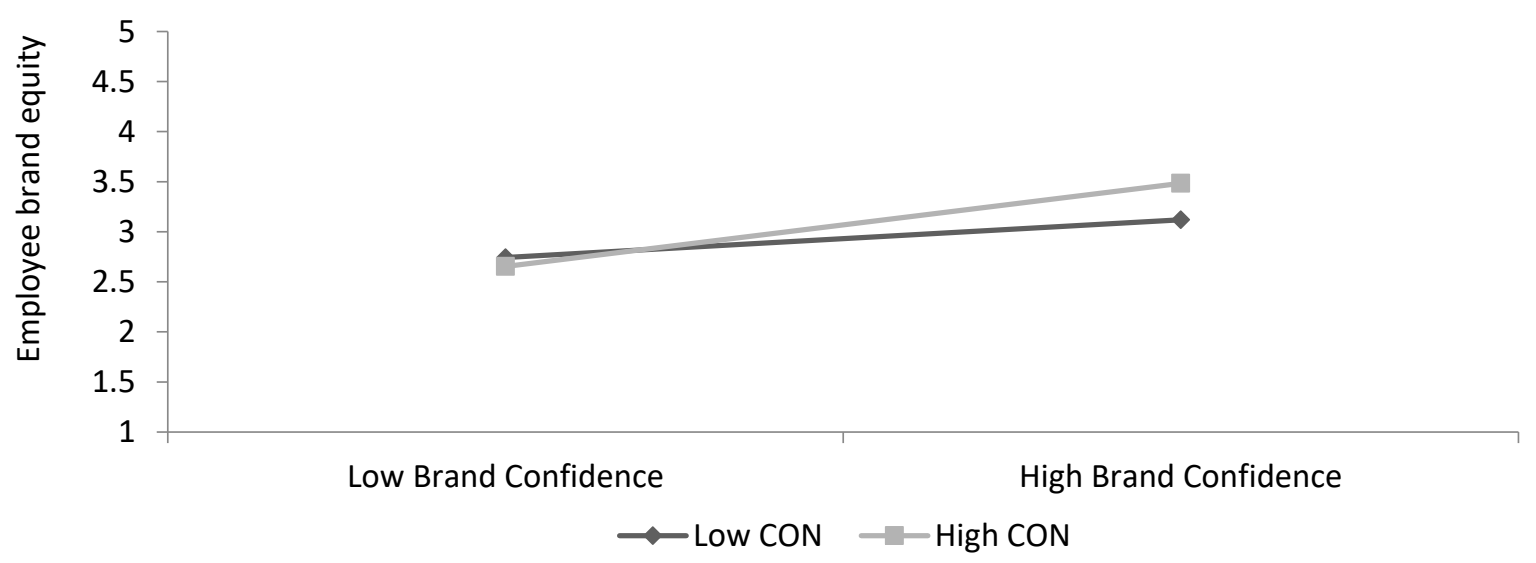

Figure 2. Moderating effect of $\mathrm{CON}$ on the relationship between $\mathrm{BC}$ and $\mathrm{EBE}$ in conventional banking

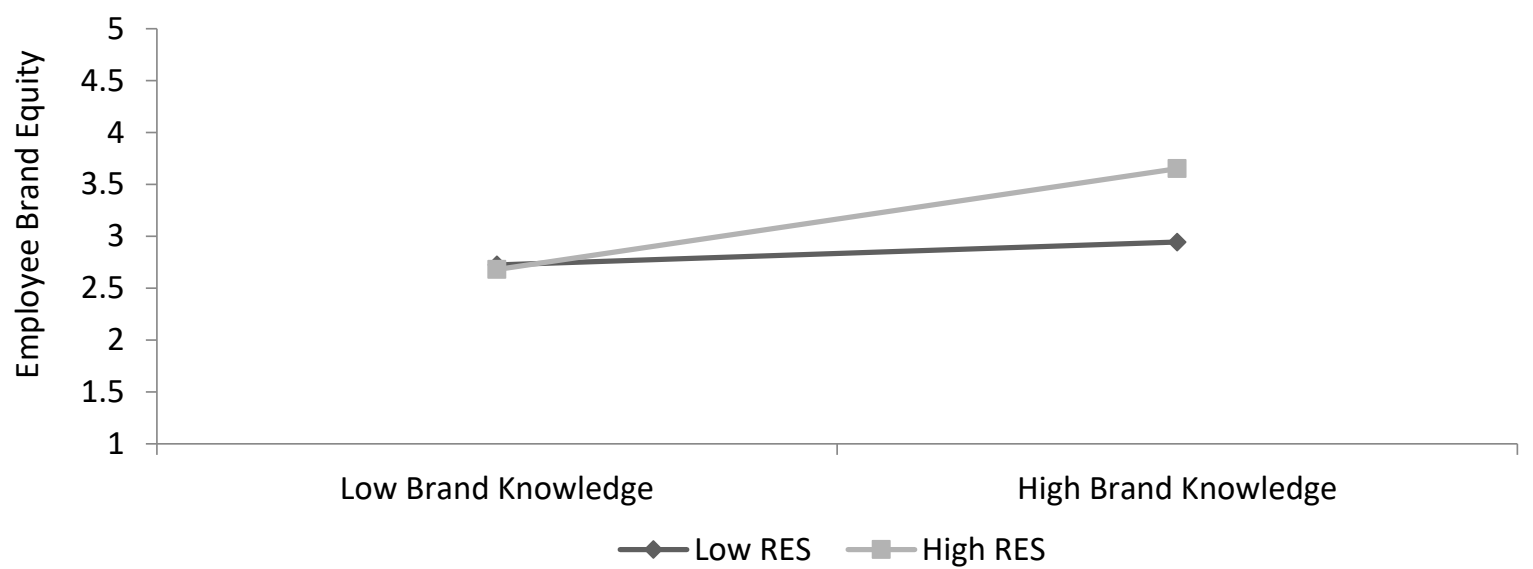

Figure 3. Moderating effect of RES on the relationship between BK and EBE in conventional banking

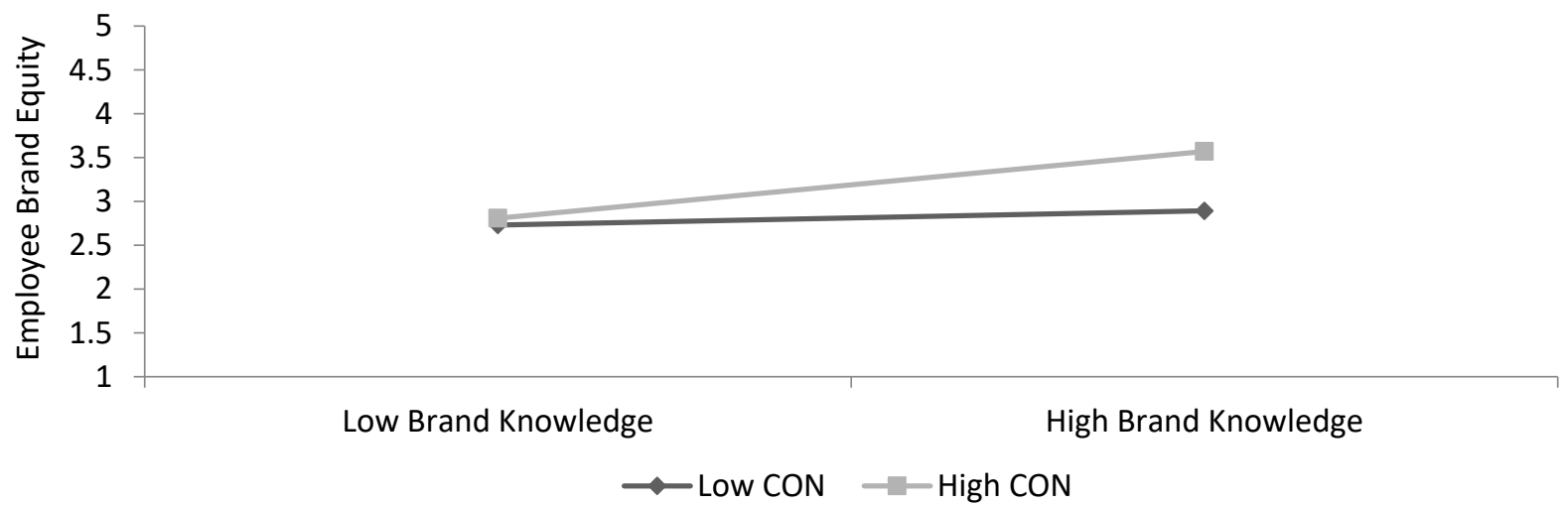

Figure 4. Moderating effect of CON on the relationship between BK and EBE in Islamic banking 
The effect of BK on EBE in the condition when RES is low and high is presented by Figure 3. In the case when RES is low, the impact of BK on EBE is not substantial, as compared to the situation when RES is high. In a different way, high level of BK and RES having substantial impact on EBE, as compared to other situations when either BK or RES is low in conventional banking.
The effect of BK on EBE in the condition when $\mathrm{CON}$ is low and high is represented in Figure 4. In the case when $\mathrm{CON}$ is low, the impact of $\mathrm{BK}$ on EBE is not substantial, as compared to the situation when $\mathrm{CON}$ is high. Another way, high level of $\mathrm{BK}$ and CON having substantial impact on EBE, as compared to other situations when either BK or $\mathrm{CON}$ is low in conventional banking.

\section{CONCLUSION AND DISCUSSION}

Congruence between brand image and individuals moderates the relationship between brand confidence and employee brand equity in conventional banking. Congruence has a moderating role on the relationship between brand knowledge and employee brand equity in Islamic banking. Employee responsibility to maintain brand image also moderates the relationship between brand knowledge and employee brand equity in conventional banking.

In the case of conventional banking, the cognitive sentiments of employee brand understanding and affective sentiments of brand psychological ownerships are important. Cognitive and affective sentiments in conventional banks complete each other. An employee with high level of congruence between individual and brand image with high level of employee knowledge about the brand strengthen the behavior that they need to perform in their daily work routine. They, then, develop substantial level of employee brand equity. Similarly, high level of employee responsibility to maintain brand image and high level of employees who are clearly aware of their role in providing brand-aligned experience also have substantial effect on employee brand equity. In the case of Islamic banks, employees with high levels of congruence between individual and brand image and high level of employee brand knowledge have substantial effect on employee brand equity. Congruence between individual and brand image and employee brand equity has an insignificant relationship with employee brand equity. However, congruence as a moderator strengthens the relationship between brand knowledge and employee brand equity.

The results of this study indicated that employee brand understanding and brand psychological ownership are significantly related to employee brand equity in conventional banking. The results are supported by findings from past studies (King \& So, 2013; Piehler et al., 2016; Xiong et al., 2013), except for brand relevance with employee brand equity. By contrast, previous studies (Chang et al., 2012; Chang, Chiang \& Han, 2015; Chiang et al., 2013; Chiang, 2009) suggested that the relationship of brand psychological ownership with employee brand equity is significant in conventional banking. The relationship of employee brand understanding with employee brand equity in Islamic banking has a significant relationship, as suggested in previous studies (King \& So, 2013; Piehler et al., 2016; Xiong et al., 2013), except for behavioral relevance. The dimensions of brand psychological ownership have insignificant relationship with employee brand equity, except for the dimension of employee responsibility of maintaining brand image.

\section{LIMITATION AND FUTURE RECOMMENDATION}

This study is limited to the banking sector. The study was conducted on conventional and Islamic banks. Multi-group analysis between public sector and private sector banks is recommended for future research. This study differentiates the cognitive and affective sentiments of employee brand understanding and brand psychological ownership and checks its impact on employee brand equity. The factors that influence affective and cognitive sentiments should be examined. 


\section{REFERENCES}

1. Ahn, Y.-j., Hyun, S. S., \& Kim, I. (2015). City Residents' Perception of MICE City Brand Orientation and Their Brand Citizenship Behavior: A Case Study of Busan, South Korea. Asia Pacific Journal of Tourism Research, 21(3), 328353. Retrieved from http://www. tandfonline.com/doi/abs/10.1080/ 10941665.2015.1050422

2. Altaf, M., Iqbal, N., Mokhtar, S. S., \& Sial, M. H. (2017). Managing Consumer-Based Brand Equity through Brand Experience in Islamic Banking Journal of Islamic Marketing, 8(2). Retrieved from http://www.emeraldinsight.com/ doi/abs/10.1108/JIMA-07-20150048? af $=\mathrm{R} \&$

3. Ariff, M. (1988). Islamic banking. Asian Pacific Economic Literature, 2(2), 48-64.

4. Baumgarth, C., \& Schmidt, M. (2010). How strong is the business-to-business brand in the workforce? An empirically-tested model of 'internal brand equity' in a business-to-business setting. Industrial Marketing Management, 39(8), 1250-1260.

5. Burmann, C., \& Zeplin, S. (2005). Building brand commitment: A behavioural approach to internal brand management. The Journal of Brand Management, 12(4), 279-300.

6. Chang, A., Chiang, H.-H., \& Han, T.-S. (2012). A multilevel investigation of relationships among brand-centered HRM, brand psychological ownership, brand citizenship behaviors, and customer satisfaction. European Journal of marketing, 46, 626-662. Retrieved from https://www.researchgate.net/ publication/242140423_A_multilevel_investigation_of_relationships_among_brand-centered_ HRM_brand_psychological_ownership_brand_citizenship_behaviors_ and_customer_satisfaction

7. Chang, A., Chiang, H.-H., \& Han, T.-S. (2015). Investigating the dual-route effects of corporate branding on brand equity. Asia Pacific Management Review, 20(3), 120-129.
8. Chiang, H.-H., Chang, A., Han, T.-S., \& McConville, D. (2013). Corporate branding, brand psychological ownership and brand citizenship behavior: multilevel analysis and managerial implications. Journal of General Management, 39(1). Retrieved from http://journals.sagepub.com/doi/ abs/10.1177/030630701303900104

9. Chiang, H. H. (2009). A study of the antecedent and concequence of brand psychological ownership: scale development and multilevel approaches (Doctoral thesis), Institute of Business Management , National Chengchi University.

10. Corporation, R. (2001). A million random digits with 100,000 normal deviates. Minnesota Historical Society.

11. Fornell, C., \& Larcker, D. F. (1981). Evaluating structural equation models with unobservable variables and measurement error. Journal of Marketing Research, 18, 375-381.

12. Geisser, S. (1975). The predictive sample reuse method with applications. Journal of the American Statistical Association, 70(350), 320-328.

13. Hackman, J. R., \& Oldham, G. R. (1975). Development of the job diagnostic survey. Journal of Applied Psychology, 60(2), 159.

14. Hair , J. F., Hult, G. T. M., Ringle, C., \& Sarstedt, M. (2013). A primer on partial least squares structural equation modeling (PLS-SEM). Sage Publications.

15. Hair, J. F., Hult, G. T. M., Ringle, C., \& Sarstedt, M. (2016). A Primer on Partial Least Squares Structural Equation Modeling (PLS-SEM). SAGE Publications. Retrieved from https://www.amazon.com/PartialSquares-Structural-Equation-Modeling/dp/1452217440

16. Henkel, S., Tomczak, T., Heitmann, M., \& Herrmann, A. (2007). Managing brand consistent employee behaviour: relevance and managerial control of behavioural branding. Journal of product \& brand management, 16(5), 310-320.
17. Henseler, J., Ringle, C. M., \& Sarstedt, M. (2015). A new criterion for assessing discriminant validity in variance-based structural equation modeling. Journal of the Academy of marketing Science, 1-21. Retrieved from https://pdfs.semanticscholar.org/ad1d/cedd70ecf26cb5bdb52248b9fea180995199. pdf

18. Kahn, W. A. (1990). Psychological conditions of personal engagement and disengagement at work. Academy of Management journal, 33(4), 692-724.

19. Khan, F. (2010). How 'Islamic'is Islamic Banking? Journal of Economic Behavior \& Organization, 76(3), 805-820.

20. Kimpakorn, N., and Dinnie, K. (2009). Employees' commitment to brands in the service sector: Luxury hotel chains in Thailand. Journal of brand management, 16 , 532-544.

21. King, C. (2010). “One size doesn’t fit all" Tourism and hospitality employees' response to internal brand management. International Journal of Contemporary Hospitality Management, 22(4), 517-534.

22. King, C., \& Grace, D. (2009). Employee based brand equity: A third perspective. Services Marketing Quarterly, 30(2), 122 147.

23. King, C., \& Grace, D. (2010). Building and measuring employeebased brand equity. European Journal of marketing, 44(7-8), 938-971.

24. King, C., Grace, D., \& Funk, D. C. (2012). Employee brand equity: Scale development and validation. Journal of brand management, 19 , 268-288.

25. King, C., \& So, K. K. F. (2013). Enhancing Hotel Employees' Brand Understanding and BrandBuilding Behavior in China. Journal of Hospitality \& Tourism Research, 20, 1-25. Retrieved from http://journals.sagepub.com/doi/ abs/10.1177/1096348013491602 
26. Krejcie, R. V., \& Morgan, D. W. (1970). Determining sample size for research activities. Educational and Psychological Measurement, 30(3), 607-610.

27. Kwon, Y. (2013). The Influence of Employee-Based Brand Equity on the Health Supportive Environment and Culture-Organizational Citizenship Behavior Relation. University of Oregon.

28. Mosley, R. W. (2007). Customer experience, organisational culture and the employer brand. Journal of brand management, 15(2), 123134.

29. Nunnally, J. (1978). Psychometric methods. New York: McGraw-Hill.

30. Piehler, R., Hanisch, S., \& Burmann, C. (2015). Internal Branding - Relevance, Management and Challenges. 52-61.

31. Piehler, R., Piehler, R., King, C., King, C., Burmann, C., Burmann, C., Xiong, L., \& Xiong, L. (2016). The importance of employee brand understanding, brand identification, and brand commitment in realizing brand citizenship behaviour. European Journal of marketing, 50(9/10), 1575-1601. Retrieved from http:// www.emeraldinsight.com/doi/ abs/10.1108/EJM-11-2014-0725
32. Pierce, J. L., Kostova, T., \& Dirks, K. T. (2001). Toward a theory of psychological ownership in organizations. Academy of management review, 26(2), 298-310.

33. Pierce, J. L., Kostova, T., and Dirks, K. T. (2003). The state of psychological ownership: Integrating and extending a century of research. Review of general psychology, 7(1), 84.

34. Ringle, C. M., Wende, S., and Becker, J.-M. (2015). SmartPLS 3. Boenningstedt: SmartPLS GmbH. Retrieved from http://www.smartpls.com

35. Rousseau, D. M., \& Shperling, Z. (2003). Pieces of the action: Ownership and the changing employment relationship. Academy of management review, 28(4), 553-570.

36. Stone, M. (1974). Cross-validatory choice and assessment of statistical predictions. Journal of the Royal Statistical Society. Series B (Methodological), 111-147.

37. Terglav, K., Ruzzier, M. K., \& Kase, R. (2014). The Role of Brand- Oriented Leadership of Top management during internal branding process. 3rd Economic and Business Review Conference. Retrieved from http://www.ebrjournal.net/ocs/index.php/ebr2014/ ebr2014/paper/view/33
38. Thomson, K., de Chernatony, L., Arganbright, L., \& Khan, S. (1999). The buy-in benchmark: How staff understanding and commitment impact brand and business performance. Journal of Marketing Management, 15(8), 819-835.

39. Van Dyne, L., \& Pierce, J. L. (2004). Psychological ownership and feelings of possession: Three field studies predicting employee attitudes and organizational citizenship behavior. Journal of organizational behavior, 25(4), 439-459.

40. Weiss, H. M., \& Cropanzano, R. (1996). Affective events theory: A theoretical discussion of the structure, causes and consequences of affective experiences at work.

41. Xiong, L., King, C., \& Piehler, R. (2013). "That's not my job": Exploring the employee perspective in the development of brand ambassadors. International Journal of Hospitality Management, 35, 348-359.

42. Zafar, R., Altaf, M., Bagram, M. M. M., \& Hussain, H. (2012). Religiosity, as Determinant of Turnover Intention: An Exploratory Study. The Journal of Commerce, 4, 1-8. 